\title{
The relation between geomorphological features and species richness in the low flow channel of the Warche, downstream from the Bütgenbach dam (Ardennes, Belgium)
}

\author{
Ali A. Assani ${ }^{a}{ }^{\text {** }}$, François Petit ${ }^{\mathrm{b}}$, Louis Leclercq ${ }^{\mathrm{c}}$ \\ a Laboratoire d'hydro-climatologie et de géomorphologie fluviale, Section de géographie, \\ Université du Québec à Trois-Rivières, Pavillon Léon-Provencher, 3351, \\ Boulevard des Forges, Trois-Rivières, Que., Canada G9A 5H7 \\ ${ }^{\mathrm{b}}$ Département de Géographie physique et Quaternaire, Université de Liège, \\ Allée du 6 Août, B11, SART-TILMAN, B4000 Liège, Belgium \\ ${ }^{\mathrm{c}}$ Université de Liège, Station scientifique des Hautes-Fagnes, 137, \\ rue de Botrange, Mont-Rigi, B4950 Waimes, Belgium
}

Received 23 February 2005; received in revised form 1 February 2006; accepted 17 February 2006

\begin{abstract}
The Butgenbach dam, built on the Warche River (Ardennes, Belgium) in 1931 brought about two major changes: a significant reduction in the frequency and magnitude of the minimum discharges during the growing season (April-September) and the formation of numerous new geomorphological features (islets, pebble bars and rock outcrops) in the low flow channel. These changes have lead to an increase in the number of vascular plants downstream from the dam. Between 1994 and 1997, 74 species (bryophytes and phanerogams) were found downstream from the dam and 12 species were identified upstream. Downstream, most of the species are typical of damp semi-natural grasslands and of the banks of the Haute Ardennes - environments both characterised by oligotrophy. Euryoecious species (with a wide ecological range) and nitrophile species (that indicate pollution of the Warche from urban effluents and agricultural fertilisers) are also present. However, the distribution of plant species in the low flow channel is very heterogeneous. The number of species varies from one geomorphological unit to another. Species are more numerous on islets ( 54 species) than on rock outcrops ( 35 species) and gravel bars ( 28 species). On the islets, the number of species present varies in accordance with the degree of erosion. The islets that are most eroded and those that are least eroded display a poor range of flora. The degree of erosion influences the depth of silt, pebbles and litter on the islets. With regard to rock outcrops, the wealth of flora present depends on the form they take. Stratified outcrops are richer in flora than protruding outcrops. The number of plant species present on gravel bars depends on the frequency and the scale of remobilisation of pebbly material by floods. Following large floods, the vegetation cover and the number of different species decreases. But, if the sites remain stable, the number of species first of all increases, only then to decrease due to the proliferation of competitive species such as Phalaris arundinacea L. The ranges of species found on the different geomorphological features do not display a high degree of similarity. Canonical correlation analysis reveals that the density and the total number of species on geomorphological features are most strongly influenced by the proportion of fine particulates $(<2 \mathrm{~mm})$.
\end{abstract}

(C) 2006 Elsevier B.V. All rights reserved.

Keywords: Regulated river; Impact of dams; Species richness; Canonical correlation analysis; Gravel bed river; Belgium

\section{Introduction}

Studies of the impacts of dams on vegetation are quite common, but most are devoted to the vegetation of flood plains and banks. Few studies have been based on the low flow channel (Clarke, 2002), which is generally colonised by algae

\footnotetext{
* Corresponding author. Tel.: +1 819376 5011; fax: +1 8193765179 .

E-mail address: Ali_Assani@uqtr.ca (A.A. Assani).
}

and/or by strictly aquatic species, due to the almost permanent presence of water (Petts, 1984; Cazaubon and Giudicelli, 1999; Burns and Walker, 2000; Bertrand et al., 2001). Sometimes certain terrestrial species may adapt to these conditions of excessive hydromorphy (Riis et al., 2001; Bernez et al., 2004). However, when the hydrological impacts of dams result in a significant decrease in flood and low water discharges, the low flow channel may be invaded by non-aquatic vegetation, reducing its width (Williams and Wolman, 1984; Chang and Crowley, 1997; Friedman et al., 1998). On the other hand, when 
the discharge increases downstream from the dam, channel widening generally results (Church, 1995), which causes riparian vegetation to recede (Dominick and O'Neill, 1998).

One of the major factors influencing the colonisation of the low flow channel by pioneer vegetation is undoubtedly the type of habitat (Riis et al., 2001; Bernez et al., 2004). The types of habitats correspond to different geomorphological features developed in the low flow channel. Despite the influence of this factor, there is still a paucity of work devoted to the relationship between the geomorphological features developed in the low flow channel and the species richness of pioneer plants (Fernandez-Allaez and Fernandez-Allaez, 1994; BaattrupPedersen and Riis, 1999; Bernez et al., 2004). However, some studies have looked at how vegetation colonises pebble bars (Langlade and Décamps, 1994, 1995). This vegetation is generally found on the margin of the low flow channel, except in the case of braided rivers, and is only inundated by floods higher than the bankfull.

Downstream from the Butgenbach dam, changes in the hydrological regime have led to a significant decrease in magnitude and frequency of daily minimum discharges. The discharge released from April to September (a period that includes the growing season) now only takes up one portion of the low flow channel, which itself has doubled in width since the dam's construction in 1930 (Assani and Petit, 2004). Thus, most of the low flow channel remains clear of water, allowing numerous non-aquatic plant species to settle. Furthermore, strong floods, despite their rarity, have shaped many geomorphological features that provide a diversity of habitat types. The aim of this article is to analyse the impact of the resulting hydrological and morphological changes on the species richness of low flow channel vegetation downstream from Butgenbach. The vegetation of the flood plain and the riverbanks have not been included in this study as these are subject to anthropogenic influence downstream from the dam. Indeed, the entire floodplain is used for pasture and regularly subject to amendments. Such practice results in a pronounced impoverishment of plant species.

This study is based on the following hypotheses:

- The reduction of the magnitude and frequency of minimum discharges during the growing season (Assani et al., 1999) and the diversity of geomorphological features (Assani and Petit, 2004) lead to an increase in the number of vegetative species downstream from the dam.

- Furthermore, due to their morphological impacts and despite their rarity, the occurrence of discharges greater than the bankfull, can significantly alter the composition of species on certain features downstream from the dam.

\section{Description of the study site}

\subsection{The Warche catchment}

The area of the catchment upstream from the Butgenbach dam is around $80 \mathrm{~km}^{2}$, spread out in relatively equal proportions between the Warche and its main tributary, the Holzwarche. At the level of the Robertville dam, the area of the catchment is approximately $118 \mathrm{~km}^{2}$ (Fig. 1). The rainfall regime of the north-eastern Ardennes is characterised by two maxima: one in winter (the most significant) and the second in summer (Lagiewska, 1981). On average, $1200 \mathrm{~mm}$ of rain falls annually. The annual averages of maximal and minimal air temperatures are in the order of 10 and $3{ }^{\circ} \mathrm{C}$, respectively. In winter, temperatures below $-10{ }^{\circ} \mathrm{C}$ may persist for a number of days. The river cuts into many geological formations from the

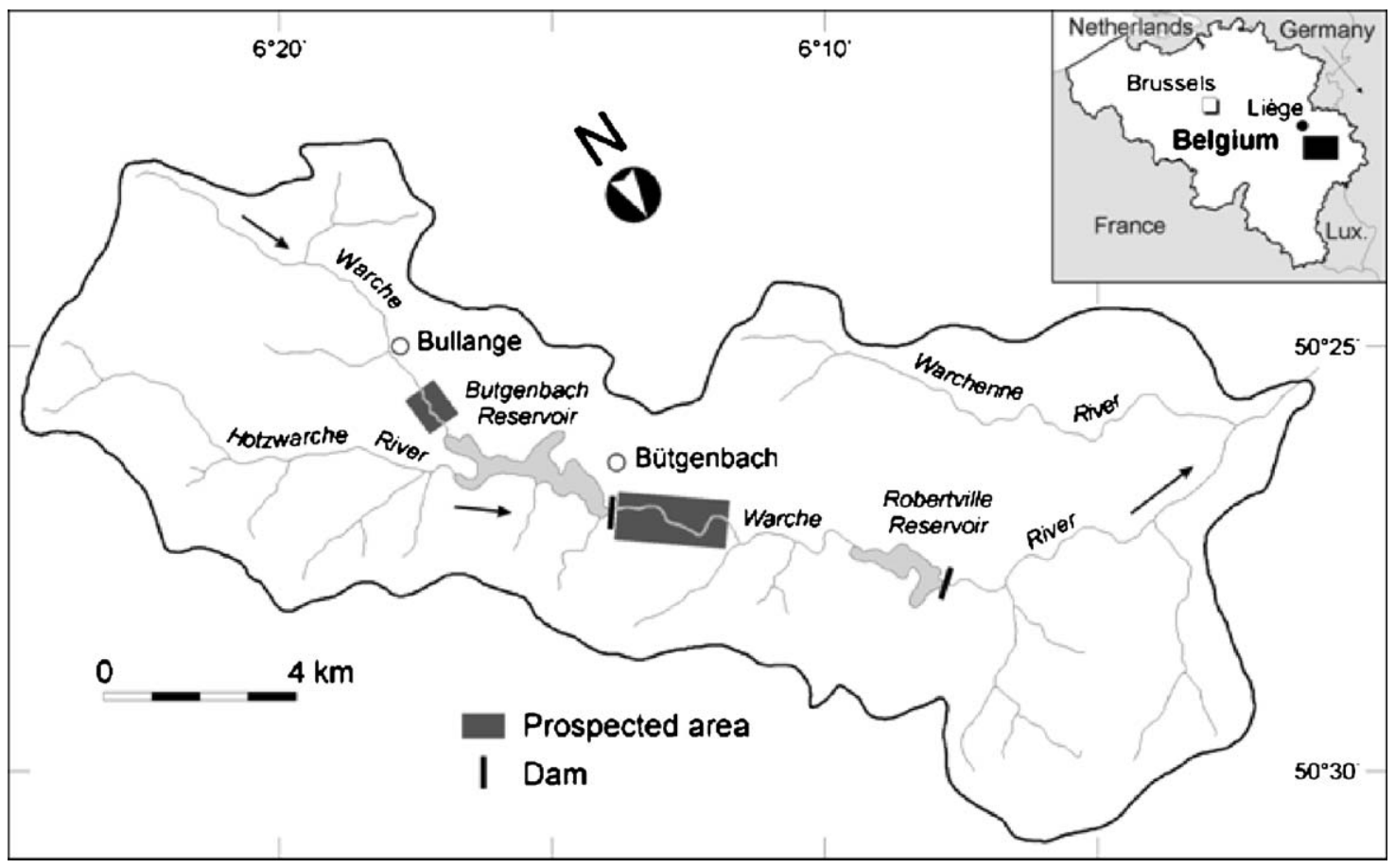

Fig. 1. Warche catchment and location of the study site. 
early Devonian period, made up of different types of rock. In the sector studied, that is upstream and downstream from the Butgenbach dam, the river essentially flows over schists, phyllites, and quartz phyllites of the lower Devonian. These rocks give an oligotrophic and slightly acidic character to the soils. The catchment is predominantly covered by grasslands and forests, which explains why, as in the other rivers of the Ardennes, there is a low rate of suspended load transported by the river (to the order of $20 \mathrm{t} \mathrm{km}^{-2}$ year ${ }^{-1}$, Lemin et al., 1987). In the northern part of the Ardennes, extensive grasslands date only from the end of the 19th century, when they replaced more traditional cultivation (Christians and Daels, 1988).

In natural conditions, the Warche corresponds to the classical schema of rivers of the Ardennes with a pebbly load; its low flow channel is distinctly incised in the flood plain, which has a width of around $40 \mathrm{~m}$. This flood plain is made up of compacted silt deposits to a depth of 1-2 m, covering a pebble sheet which in turn lies on the bedrock. The rivers are therefore rarely in direct contact with the bedrock, even in the deepest pools, and flow on the gravel that is a legacy of the last cold period (Petit, 1995). Field observations allowed the bankfull discharge to be estimated at $15 \mathrm{~m}^{3} \mathrm{~s}^{-1}$, between the two dams. This value corresponds well with that put forward in a relation dealing with around thirty gravel bed rivers in the Belgian uplands. The bankfull discharge recurrence interval for rivers of this dimension is approximately 0.6 years (Petit and Pauquet, 1997).

\subsection{Modifications resulting from the dam}

The Butgenbach dam was built in 1931 in order to maintain the Robertville Lake (situated $7 \mathrm{~km}$ downstream) at its highest level. The lake serves in the production of hydroelectricity. It follows that during winter months, when the demand for electricity is greatest, daily releases of $10 \mathrm{~m}^{3} / \mathrm{s}(0.6$ bankfull discharge) are made from the Butgenbach dam. In this way, the annual frequency of this discharge has been multiplied by 45 (Assani, 1997). On the other hand, the frequency and duration of discharges superior to the bankfull have been reduced. Indeed, all of the discharges with a recurrence interval of greater than 10 years are no longer found and those with a recurrence interval of 5-10 years have been rarefied since the dam was built. Thus, since the dam's construction, the maximal discharge released has barely matched the 10-year flood, while, had the dam not been built, a 100-year flood would have been reached (Assani et al., 1999). Furthermore, throughout the spring and summer (April-September), the instream discharge $\left(0.5 \mathrm{~m}^{3} / \mathrm{s}\right)$ is systematically lower than the discharges measured under natural conditions. The depth of the water in periods of low flow is less than $20 \mathrm{~cm}$ in the section studied. Consequently, water is concentrated only in the middle of the channel. The islets, bars and numerous rock outcrops therefore remain clear of water throughout the growing season, which facilitates their colonisation by plants.

The modifications to the bed morphology and sedimentology brought about by the dam have been analysed in detail elsewhere (Assani and Petit, 2004). The present paper, therefore, will only look at the main points raised by the aforementioned study. With regard to sedimentology, the impact of the dam has been an increase in the size of the bed material. This increase results from the selective erosion of the bed's finest particles, which leads to the formation of a residual paving: the median size of the riverbed sediments downstream from the dam has become about three times greater than the median size of the material situated upstream. As far as morphology is concerned, the dam has caused a noticeable widening of the channel, a decrease in the number of riffles and pools, an increase in islets and bars and the exposure of numerous bedrock outcrops in the channel. These changes have affected the entire sector downstream from the dam (Assani and Petit, 2004). The islets evolve by erosion and end up being transformed into pebble bars. Four stages of erosion have been highlighted.

- During the first stage (type A islets), the surface of the islet is scoured by floods that are greater than the bankfull. This progressively lowers their height in relation to that of the adjacent riverbanks. Subsequently, small sized gravel transported by floods begins to accumulate at the surface.

- In the second stage (type B islets), the height of the islet continues to decrease with scouring from fine material. The gravel trapped on top and transported by floods progressively takes over the entire surface of the islet, hollowing out channels. These lengthen in a downstream direction. This type of islet is currently the most numerous in the low flow channel.

- The third stage of erosion (type $\mathrm{C}$ islets) is characterised by the multiplication of the channels and their continued progression downstream. Many end up converging and in this way intensify the erosion of the fine material which formerly made up the islet. The height of the islet continues to decrease and the depth of gravel that accumulates on the surface increases.

- In the last stage (type D islets), after the channels filled with pebbles have converged, the islet is entirely transformed into a pebble bar (median bar). The thickness of the gravel on the surface of the islet increases, sometimes resting on only a thin layer of consolidated fine particles - the remnants of the material which formerly made up the floodplain.

Two types of bars may be identified according to their location in the channel: median bars located in the middle of the channel and convexity bars, located beside the riverbanks. For rock outcrops, which are numerous in the low flow channel following incision of the bed, two types have also been distinguished according to their form, size and height relative to the low flow channel:

- Protruding rock outcrops which are blocks jutting out from the low flow channel whose size (average axis) is no greater than $30 \mathrm{~cm}$. They generally appear as isolated outcrops or in groups. During water releases from the dam, these outcrops generate considerable water turbulence due to their position jutting out from the low flow channel. 
- Stratified rock outcrops which do not jut out and whose size is greater than $30 \mathrm{~cm}$. They provoke little turbulence when compared to protruding outcrops.

Regarding its chemical composition, as a result of the major elements present in the underlying rock, the Warche is an oligotrophic river, poor in calcium. Downstream from the Butgenbach dam, despite an increase in mineralisation, the river may still be considered oligotrophic (Dawagne and Leclercq, 1998; Leclercq, 1984). The rest of the water course has for some time been subject to organic pollution and marked eutrophication, due to intensive agriculture, insufficient water treatment and local industries (especially the Büllingen dairy in the upper course). In the sector that is of chief interest to this study, downstream from the dam, one may remark a clear decrease in the level of phosphates from the period 1976-1999, which are partly trapped in the lake (Dawagne and Leclercq, 1998).

\section{Methodology and sampling sites}

\subsection{Sampling sites and sampling method}

In order to test the first hypothesis, an inventory of the different geomorphological features present in the low flow channel upstream and downstream from the dam was made. Downstream from the dam, five types of geomorphological features were identified as previously described: islets (types A-C), bars (convexity and median) and rock outcrops (protruding and stratified). For each feature, three sites were selected. Upstream from the dam, only one type of geomorphological feature was identified, namely type A islets. Thus, three sites were selected in order to compare these with the sites downstream from the dam. It should be noted that many rock outcrops may be found upstream. However, in contrast to the outcrops found downstream, those upstream are constantly covered by water and were not included in the study. In total, 21 sites downstream from the dam and three sites upstream were sampled (Table 1). The sectors sampled are presented in Fig. 1. The plants studied include terrestrial and amphibious vegetation, according to the classification of low flow channel vegetation proposed by Sand-Jensen et al. (1992). Submerged (or strictly aquatic) vegetation is therefore excluded. The latter is not widespread and exclusively

Table 1

List of sites sampled upstream and downstream from the dam

\begin{tabular}{lcc}
\hline Feature type & Area $\left(\mathrm{m}^{2}\right)$ & Width $(\mathrm{m})^{\mathrm{a}}$ \\
\hline Type A islets ${ }^{\mathrm{b}}$ & $137.7 \pm 60.74$ & $10.2 \pm 2.03$ \\
Type A islets & $133 \pm 24.06$ & $15.5 \pm 3.95$ \\
Type B islets & $116.3 \pm 27.65$ & $26.1 \pm 14.92$ \\
Type C islets & $102.3 \pm 19$ & $14.5 \pm 1.32$ \\
Convexity bars & $112.7 \pm 20.43$ & $21.0 \pm 1.40$ \\
Median bars & $60 \pm 7.21$ & $17.3 \pm 4.34$ \\
Protruding rock outcrops & $1.8 \pm 1.50$ & $15.3 \pm 0.52$ \\
Stratified outcrops & $1.3 \pm 0.97$ & $17.5 \pm 7.31$ \\
\hline a Bankfull width of channel. & & \\
b Upstream from dam. & &
\end{tabular}

composed of two species (Callitriche sp. and Ranunculus penicillatus) downstream from the dam. The same species colonise riffles and submerged rock outcrops in abundance upstream from the dam.

To compare the species richness of the different geomorphological features two steps were followed.

The first step involved sampling the vegetation using quadrats of $2 \mathrm{~m} \times 3 \mathrm{~m}$. On each site, seven quadrats that did not overlap were randomly sampled. This number was limited to 7 as it was difficult to randomly sample more on some sites due to the limited surface area. For the same reasons, no quadrats were used on the rock outcrops. Therefore, at this stage, these outcrops were not sampled downstream from the dam. This approach allowed us to estimate species densities. Secondly, as sampling using a quadrat does not allow all of the species on a given site to be collected, an exhaustive sampling of all of the sites was undertaken. Indeed, each site was entirely prospected in order to identify the species that lay outside of the quadrats. The aim of this second survey was to allow the total number of species on each site, regardless of its surface area, to be compared. For this second step, rock outcrops that had not been sampled the first time round were included.

For the second hypothesis, the impact of the only discharge greater than the bankfull released downstream from the dam during the course of this study (1994-1997), was analysed. This analysis was based on the comparison of vegetative species surveyed in July 1995 and in July 1997. The aim was to determine the consequences of the morphological modifications to the different sites (which took place as a result of high floods) on the species richness. During the period from June 1994 to July 1997 , a very important flood was recorded, which took place at the end of December 1994 and the beginning of January 1995. In natural conditions, the flood attained a maximum discharge of $52.3 \mathrm{~m}^{3} / \mathrm{s}$, which corresponds to a recurrence interval of around 20 years. During this flood, the dam released $20.5 \mathrm{~m}^{3} / \mathrm{s}$. The geomorphological impacts of this flood downstream from the dam were significant. However, the morpho-sedimentological changes induced by the flood vary from one geomorphological feature to another (Assani, 1997). On the islets, the researchers observed spreading of the surface pebbles, erosion of fine material leading to a lowering of the islet's surface (type A islets), elongation of the channels, as well as an accumulation of gravel on the summit and on the surface of type $B$ and $C$ islets. Modifications to the bars resulted almost exclusively in a more or less significant accumulation of gravel. In this way, for example, on one of the median bars sampled, this accumulation even exceeded $20 \mathrm{~cm}$ on average. However, this deposition was preceded by erosion, as all of the marked pebbles on the bars were mobilised. This alternation of phases of erosion and accumulation indicate that the gravely material of the bars is subject to a high degree of remobilisation during floods.

\subsection{Statistical analysis}

We have compared the species richness of the different geomorphological features by means one-way analysis of variance (Dagnelie, 1986; Legendre and Legendre, 1998). 
Table 2

Comparison of the number of species upstream and downstream from dam

\begin{tabular}{|c|c|c|c|c|c|}
\hline \multirow[t]{2}{*}{ Features } & \multicolumn{3}{|c|}{ Species richness in quadrats $(n=21)$} & \multicolumn{2}{|c|}{$\begin{array}{l}\text { Species richness on features } \\
(n=3)\end{array}$} \\
\hline & $\mathrm{X} \pm$ S.E. & Range & Scheffé's test & $\mathrm{X} \pm$ S.E. & Range \\
\hline Type A islets ${ }^{\mathrm{a}}$ (a) & $3 \pm 2.19$ & $1-8$ & $(\mathrm{~b})^{\mathrm{b}}$ & $8 \pm 5.29$ & $\overline{2-12}$ \\
\hline Type A islets (b) & $14 \pm 4.08$ & $6-20$ & $(a, f)$ & $25 \pm 1.53$ & $24-27$ \\
\hline Type B islets (c) & $19 \pm 5.15$ & $10-28$ & $(e, f)$ & $31 \pm 2.52$ & $29-34$ \\
\hline Type C islets (d) & $17 \pm 4.76$ & $7-25$ & $(e, f)$ & $24 \pm 3.61$ & $21-28$ \\
\hline Convexity bars (e) & $11 \pm 3.75$ & $5-18$ & $(d, c)$ & $22 \pm 2.08$ & $20-24$ \\
\hline Median bars (f) & $6 \pm 2.32$ & $3-10$ & $(b, c, d)$ & $13 \pm 1.53$ & $12-15$ \\
\hline Protruding rock outcrops & - & - & & $18 \pm 2.52$ & $16-21$ \\
\hline Stratified outcrops & - & - & & $10 \pm 4.58$ & $6-15$ \\
\hline
\end{tabular}

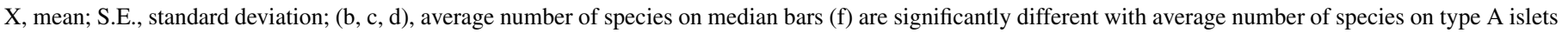
(b); type B islets (c) and type C islets (d).

${ }^{a}$ Upstream from dam.

b Test- $t$ used.

When the averages of the populations compared are globally different, Scheffé's test is applied. For the second hypothesis, Chi-squared and paired-samples $t$-tests were applied in order to compare the number of species and the percentage of vegetative regrowth in 1995 and 1997. In order to compare the degree of similarity between the data obtained from the different geomorphological features, the Jaccard index was calculated (Dagnelie, 1986). The nomenclature of Belgian flora (Lambinon et al., 2004) was referred to for the designation of plant species.

Finally, to determine the factors governing spatial variability in the number of species from one site to another, canonical correlation analysis was used (Afifi and Clark, 1996). This allows the correlation coefficients between the variables to be maximised and also takes account of mutual interactions. This analysis was calculated from two dependent variables (the average number of species per quadrat $(2 \mathrm{~m} \times 3 \mathrm{~m}))$, and the total number of species per site, as well as the following independent parameters: width, average depth of the bed at the bankfull, hydraulic radius, local slope, distance of the site from the dam, the proportion (in \%) of elements $<2 \mathrm{~mm}$ and the area of the site. With the exception of slope, average depth and the hydraulic radius, the all variables underwent a logarithmic transformation.

\section{Results}

\subsection{Comparison of the number of species between the different geomorphological features upstream and downstream from the dam}

The average number of species per quadrat differed significantly between islets and pebble bars (Tables 2 and 3).
The mean number of species per quadrat is higher on islets (16 species on average) than on bars. If the geomorphological features are considered separately, there is a significant difference between type A islets and the two other types (B and $\mathrm{C}$ ). The average number of species increases by $29 \%$ as one moves from stage A to stage B. Also, the number of species was higher on convexity bars than on median bars. In accordance, the total number of species was higher on the islets than on the other sites. Furthermore, this number is higher for type B islets than for the other two types of islets. The total number of species on pebble bars was higher than on rock outcrops. However, the total number of species is greater on stratified outcrops than on median pebble bars.

Downstream from the dam, we observed a total 74 species. Euryoecious species were the most numerous on each of the geomorphological features (Fig. 2). Nitrophilous species, the second most important ecological group, were more plentiful on the bars than on the other two geomorphological features. The proportion of species characteristic of the riverbanks was low on gravel bars $(<9 \%)$ but relatively high on type A islets $(19 \%)$ and protruding rock outcrops (17\%). Finally, bryophytes were only present on rock outcrops. The average number of species per site increased upstream to downstream from dam (Table 2) on the type A islets. The degree of similarity between the surveys of the different geomorphological features both upstream and downstream from the dam was relatively low (less than $50 \%$ ).

Table 4 shows the values of the coefficients of canonical correlation analysis. Both of the canonical correlation coefficients are statistically significant. The value of the first coefficient is particularly high. This indicates a close link

Table 3

Comparison of the number of species sampled in the quadrats downstream from the dam

\begin{tabular}{llrrr}
\hline Sources of variation & Sum of squares & d.f. & Mean-square & $F$-ratio \\
\hline Differences between sites & 2079.238 & 4 & 519.810 & 30.466 \\
Differences within sites & 1706.190 & 100 & 17.062 & 0.00001 \\
Total & 3785.428 & 104 & & \\
\hline
\end{tabular}

Results of one-way analysis of variance. d.f., degree of freedom. 


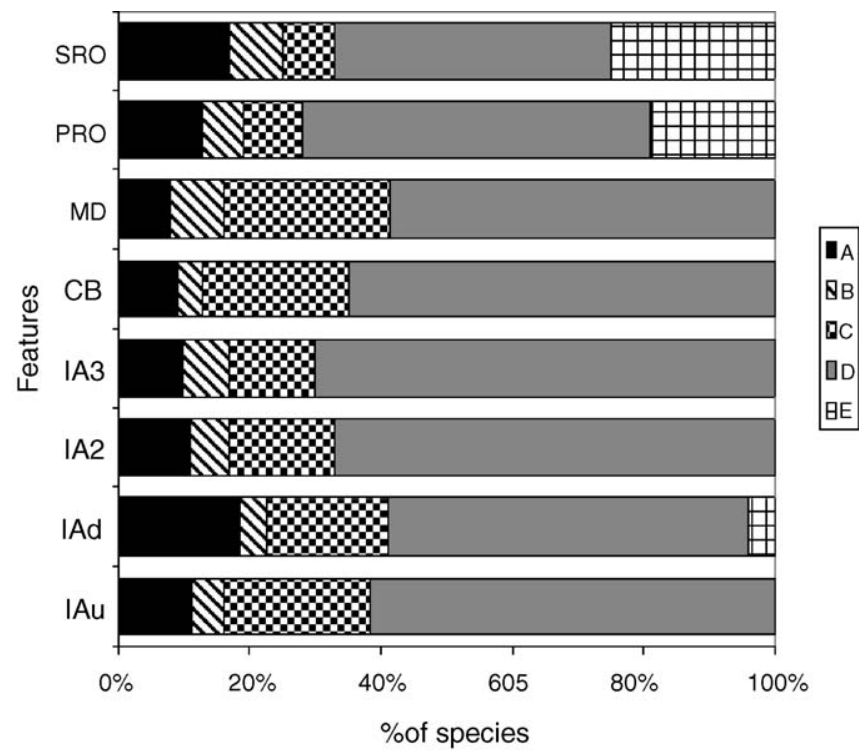

Fig. 2. Distribution of ecological groups on the different geomorphological features. IAu, type A islet upstream from dam; IAd, type A islet downstream from dam; IA2, type B ilset; IA3, type C islet. CB, concavity bars; MB, median bars; PRO, protruding outcrops; SRO, stratified outcrops. A, riverbank species; $\mathrm{B}$, acidophile species; C, nitrophile species; D, euryoecious species, E, bryophytes species.

between the two groups of variables. Table 5 shows, on one hand, the coefficients of the correlations between the original dependent variables (the average number of species per quadrat and the total number of species per site) and the new canonical variables $(V)$. On the other hand, it shows, the correlations between the original independent parameters and the new canonical variables $(W)$. The first new canonical variable $\left(V_{1}\right)$ is strongly linked to the two original dependent variables. With regard to the original independent parameters, the proportion of fine sediments $(<2 \mathrm{~mm})$ is strongly linked to the new canonical variable $\left(W_{1}\right)$. When $V_{1}$ and $W_{1}$ are correlated, one may see that the proportion of fine sediment strongly influences both average number of species per quadrat (density) and the total number of species per site. It should be underlined that the variable of the area of the site $(S)$ also correlates well with the new canonical variable $\left(W_{1}\right)$. As a result, this also influences, though only moderately, the density and the total number of species on the sites. Morphological variables such as depth, distance from the dam and the slope of the bed do not seem to influence the floristic diversity of the sites.

Table 4

Relationship between the number of species and the explanatory factors downstream from the dam

\begin{tabular}{lllll}
\hline Canonical root & Canonical correlation & $F$-value & d.f. & $p>F$ \\
\hline$\lambda_{1}$ & 0.97 & 7.30 & $(14,12)$ & 0.0007 \\
$\lambda_{2}$ & 0.89 & 4.42 & $(6,7)$ & 0.0362 \\
\hline
\end{tabular}

Canonical correlation analysis statistics. d.f. $=$ degree of freedom.
Table 5

Correlations between original (dependent and independent) variables and new canonical variables $(\mathrm{V}$ and $\mathrm{W}$ )

\begin{tabular}{lllll}
\hline Original variables & $V_{1}$ & $V_{2}$ & $W_{1}$ & $W_{2}$ \\
\hline $\begin{array}{l}\text { Average number of } \\
\text { species per quadrat }\end{array}$ & 0.88 & -0.17 & & \\
$\begin{array}{l}\text { Total number } \\
\text { species per feature }\end{array}$ & 0.98 & 0.48 & & \\
$\begin{array}{l}\text { Width at bankfull } \\
\quad \text { discharge }\end{array}$ & & & & \\
$\begin{array}{l}\text { Average depth at } \\
\text { bankfull discharge }\end{array}$ & & 0.17 & 0.13 \\
$\begin{array}{l}\text { Hydraulic radius at } \\
\text { bankfull discharge }\end{array}$ & & 0.16 & 0.12 \\
$\begin{array}{l}\text { Distance from the dam } \\
\text { The proportion of } \\
\quad \text { fine sediments }(<2 \mathrm{~mm})\end{array}$ & & 0.02 & -0.06 \\
$\begin{array}{l}\text { Area } \\
\text { Slope }\end{array}$ & & -0.22 & 0.57 \\
& & & 0.92 & 0.17 \\
\end{tabular}

\subsection{Effects of floods on species richness downstream from} the dam

Table 6 shows the results of the surveys conducted after a flood. The Chi-squared and paired-samples $t$-tests revealed a significant increase $(p<0.001)$ in the vegetative regrowth on both types of gravel bars and the number of species on the median bars in 1997 only. Thus, in 2 years, vegetation cover has gone from $5 \%$ to $100 \%$ of the total area of the bars. With regard to the median bars, the new species belong to those species characteristic of the riverbanks in particular, as well as nitrophilous (Galeopsis tetrahit L., Lamium album L., Heracleum sphondylium L., Tanacetum vulgare L., etc.) and euryoecious species (Alchemilla xanthochlora Rothm., Barbarea intermedia Boreau, Dactylis glomerata L., Lychnis floscuculi L., Polygonum aviculare L., Taraxacum sp., etc). These vegetation changes undoubtedly result from the relative stability of these sites throughout the last 2 years. As the gravely material has not been reworked by floods, the seeds of various species could germinate and take root. Meanwhile, on the sites that have not undergone extensive reworking during floods such as islets and protruding rock outcrops, no significant changes of vegetation were observed.

\section{Discussion and conclusion}

An inventory of 74 species of plants in total was made downstream from the Bütgenbach dam. This number is much greater than that of most low flow channels of natural rivers in the Hautes Ardennes (Petit and Schumacker, 1985; Schumacker, 1976). Upstream from the dam, the total maximum number of species present was no more than 12. Two factors may explain the increase in the number of species downstream from the dam. Firstly, the decrease of the instream discharge downstream from the dam during the growing season: due to this decrease, may sites are no longer submerged, allowing nonaquatic species to colonise the low flow channel. Secondly, the morphological changes that have occurred downstream from the dam have led to the formation of diverse geomorphological 
Table 6

Comparison of vegetation cover and number of plant species in July 1995 and in July 1997 after the January 1995 flood

\begin{tabular}{|c|c|c|c|c|c|c|c|c|c|c|c|c|}
\hline & \multicolumn{2}{|c|}{ Rock outcrops $^{\mathrm{a}}$} & \multicolumn{2}{|c|}{ Type A islets } & \multicolumn{2}{|c|}{ Type B islets } & \multicolumn{2}{|c|}{ Type $\mathrm{C}$ islets } & \multicolumn{2}{|c|}{ Convexity bars } & \multicolumn{2}{|c|}{ Median bars } \\
\hline & 1995 & 1997 & 1995 & 1997 & 1995 & 1997 & 1995 & 1997 & 1995 & 1997 & 1995 & 1997 \\
\hline$\%$ Vegetation cover & 100 & 100 & 100 & 100 & 100 & 100 & 100 & 100 & 5 & 100 & 5 & 100 \\
\hline Number of species & 35 & 35 & 27 & 27 & 53 & 54 & 30 & 30 & 23 & 28 & 12 & 22 \\
\hline
\end{tabular}

${ }^{a}$ Both types of outcrop were grouped together.

features in the low flow channel: islets at different stages of erosion, different types of pebble bars and rock outcrops. These features are not present upstream from the dam. For vegetative species, these different geomorphological features constitute a more diverse range of habitat types.

The group of pioneer species that has colonised the low flow channel is, for the most part, composed of euryoecious species $(65 \%)$ that show a greater capacity to adapt than the species characteristic of the riverbanks. These are represented by only six species. However, one of these six (Phalaris arundinacea) is the only one present and the most commonly found on all of the sites. One should also note that nitrophile species are present on all of the morphological features.

In the channel, the number of species per site varies from one geomorphological feature to another. The number of species is higher on islets than on rock outcrops and pebble bars. For a given geomorphological feature, variation in the species richness was also observed. For islets, the number of species varied according to the degree of erosion of the feature. The number of species is low for the least (type A) and the most (type C and D) eroded features. With regard to bars, their location influences the number of species per site. Median bars, situated in the middle of the channel and thus exposed to high velocities, have a poorer range of species than convexity bars. As for rock outcrops, variations in species richness are related to their degree of exposure to flow. Protruding rock outcrops have a poorer range of species than stratified rock outcrops. The latter are less exposed to flow than the former. Finally, the degree of floral similarity between the different geomorphological features is not high, with only one species found on all of the sites. Furthermore, and $90 \%$ of the Jaccard similarity coefficients are below 40.

Canonical correlation analysis revealed that the number of species per sites is strongly influenced by the proportion of fine sediments $(<2 \mathrm{~mm})$. The influence of fine elements and the proportion of silt in particular, on species richness was examined by Langlade and Décamps (1995) on a pebble bar. The authors demonstrated, amongst others, that the number of species first of all increases in proportion to the amount of silt, which plays an important role due to its capacity for hydration and resistance to drying out. Then, the number of species decreases once the amount of silt exceeds a certain threshold. In this case, a high proportion of silt contributes to the formation of a crust at the surface which may hinder plants from sprouting. These observations seem to be confirmed in the case of the Warche. Indeed, when the number of species per site is compared for the islets, it may be seen that the number increases first of all in proportion to the amount of fine sediment up to a maximum (type $\mathrm{B}$ islet) and then decreases (type $\mathrm{C}$ islet). The second factor that accounts for the spatial variability of the species richness is the size of the site. The more limited the area, the fiercer competition could be between the species present. Only very competitive species such as $P$. arundinacea may survive. This factor explains the extreme paucity of species observed on protruding rock outcrops where the natural precariousness of such a site is exacerbated by the cramped nature of the habitat.

The amount of fine sediments and the area of the sites do not explain the higher number of plant species present on stratified rock outcrops compared to gravel bars. The relative paucity of species on the latter may be attributed to the fact that they are frequently reworked by floods. As already demonstrated, following an important flood event, the number of plant species decreases considerably, especially on median bars, only then to grow progressively during a period of respite. Our observations confirm the impact of floods on the dynamics of species on pebble bars as documented by Langlade and Décamps (1994, 1995). From analysing the mobilisation of pebbles painted in situ on the bars it becomes clear why the number of species on the pebble bars is reduced following a flood. Observations revealed that all of the marked pebbles were moved despite a positive sedimentary balance (accumulation) observed overall following the flood. This movement indicates that the pebbles bars have undergone erosion which preceded a phase of accumulation. It is during the erosion phase that the seeds buried in the sediment are carried away, therefore reducing the available stock. The sediments that subsequently accumulate on the site are probably lacking seeds. Consequently, following an important flood the stock of seeds may be decrease. In conclusion, we argue that it is not the burial of seeds beneath the sediment that explains the decline of species on the gravel bars, but rather the erosion of the seeds that precedes the phase of accumulation. However, in some cases, burial may be the case if the accumulation phase is not preceded by an erosive phase.

Furthermore, our observations did not highlight the influence of other environmental factors, such as width and depth, on the species richness. The influence of these factors has already been detailed by other authors (Bernez et al., 2004). With regard to the presence of organic litter, its influence could not be quantified. However, it seems that the decrease in species richness observed on type A islets may be due in part to the presence of a significant layer of litter which was observed. Due to the height of the islets, this litter layer could not be removed by the water current during releases from the dam. As Langlade and Décamps (1994) have shown, the accumulation of a substantial layer of litter is not favourable to the growth of 
pioneer vegetation as it provides shade and serves as a physical barrier to sprouting plants. Moreover, such litter is associated with the emission of phytotoxins. In addition, the presence of a substantial layer of litter associated with a reduction of the current, favours the accumulation of silt ("comb effect") on the site. In turn these accumulations of litter and silt reduce the number of species.

In conclusion, the effects of the Butgenbach dam are beneficial from a strictly botanical point of view. Large releases, despite their rarity, contribute to the formation of a diverse array of geomorphological units colonised by a variety of flora. These include, amongst others, species characteristic of the ancient hay meadows of the Ardennes which are no longer found on the flood plain downstream from the Butgenbach dam. The low flow channel thus become a refuge for species that have become increasingly rare and therefore deserves to be included in natural reserves. To preserve this wealth of flora would require that some sites, such as islets and stratified outcrops, are mowed annually, in order to avoid the proliferation of the most competitive species ( $P$. arundinacea, Filipendula ulmaria, etc.). On the gravel bars, the remobilisation of material by floods assures that these features are 'mowed' in a natural fashion, keeping the sites open and therefore favourable to floral diversification. Thus, it seems that a release in the order of $20 \mathrm{~m}^{3} / \mathrm{s}$ every 2 years would allow periodical remobilisation without causing erosion of the gravel bars, which is the reason for the reduction of the seed stock available on these bars.

\section{Acknowledgements}

The authors would like to thank the MET-SETHY (Ministère de l'Équipement et des Transports, Service d'Études hydrologiques), the SCENN (Service des Cours d'Eau non navigable) as well as ELECTRABEL (who manage the Butgenbach dam) who have made a considerable amount of information available and N. Shields for assistance in translating. The AGCD (Administration Générale de la Coopération belge au Développement) provided financial support for the thesis of Mr. Assani.

\section{References}

Afifi, A.A., Clark, V., 1996. Computer-aided Multivariate Analysis, 3rd ed. Chapman and Hall, New York, 505 pp.

Assani, A.A., 1997. Recherche d'impacts d'une retenue sur le comportement d'une rivière ardennaise (hydrologie, sédimentologie, morphologie et végétation). Cas du barrage de Butgenbach sur la Warche (Belgique). Thèse doctorat en Sc. Géogr., Université de Liège, 482 pp.

Assani, A.A., Petit, F., 2004. Impacts of hydroelectric power releases on the morphology and sedimentology of the bed of the Warche River. Earth Surf. Process. Landforms 29, 133-143.

Assani, A.A., Petit, F., Mabille, G., 1999. Analyse des débits de la Warche aux barrages de Butgenbach et de Robertville (Ardenne belge). Bull. Soc Géogr. Liège $36,17-30$.

Baattrup-Pedersen, A., Riis, T., 1999. Macrophyte diversity and composition in relation to substratum characteristics in regulated and unregulated Danish streams. Freshwater Biol. 42, 375-385.
Bernez, I., Daniel, H., Haury, J., Ferreira, M.T., 2004. Combined effect of environmental factors and regulation on macrophyte vegetation along three rivers in Western France. River Res. Appl. 20, 43-59.

Bertrand, C., Siauve, V., Fayolle, S., Cazaubon, A., 2001. Effects of hydrological regime on the drift algae in a regulated Mediterranean River (River Verdon, Southeastern France). Regul. River: Res. Mange. 17, 407-416.

Burns, A., Walker, K.F., 2000. Effects of water level regulation on algal biofilms in the River Murray, South Australia. Regul. River: Res. Mange. 16, 433444

Cazaubon, A., Giudicelli, J., 1999. Impact of the residual flow on the physical characteristics and benthic community (algae, invertebrates) of a regulated Mediterranean River: the Durance, France. Regul. Rivers: Res. Mange. 15, 441-461.

Chang, M., Crowley, C.M., 1997. Downstream effects of a dammed reservoir on streamflow and vegetation in East Texas. In: Sustainability of Water Resources under Increasing Uncertainty, IAHS Publ No. 240, pp. 267275

Christians, C., Daels, L., 1988. Belgium: a geographical introduction to its regional diversity and its human richness. Bull. Soc. Géogr. Liège 24, 180.

Church, M., 1995. Geomorphic response to river regulation. Case studies and time-scales. Regul. River: Res. Mange. 11, 3-22.

Clarke, S.J., 2002. Vegetation growth in rivers: influence upon sediments and nutrients. Prog. Phys. Geogr. 26, 159-172.

Dagnelie, P., 1986. Analyse Statistique à Plusieurs Variables. Les Presses Agronomiques de Gembloux, Gembloux, 463 pp.

Dawagne, E., Leclercq, L., 1998. Étude du bassin versant de la Warche par bioindicateurs algaux et risques d'eutrophisation au niveau du barrage de Bütgenbach. Plan d'action théorique., $182 \mathrm{pp}$.

Dominick, D.S., O'Neill, P., 1998. Effects of flow augmentation on stream morphology and riparian vegetation: upper Arkansas River basin, Colorado. Wetlands 18, 591-607.

Fernandez-Allaez, C., Fernandez-Allaez, M., 1994. The macrophyte communities of the Sil basin (NW Spain) and their relationship with the environmental variables. Intern. Verein. Theor. Ange. Limn. 25, 1709-1715.

Friedman, J.M., Osterkamp, W.R., Scott, M.L., Auble, G.T., 1998. Downstream effects of dams on channel geometry and bottomland vegetation: regional patterns in the Great Plains. Wetlands 18, 619-633.

Lagiewska, H., 1981. Classification des régimes pluviométriques annuels de la Belgique, à partir de l'analyse harmonique. Bull. Soc. Géogr. Liège 16-17, $83-100$

Lambinon, J., Delvosalle, L., Duvigneaud, J., 2004. Nouvelle flore de la Belgique, du Grand-Duché de Luxembourg, du nord de la France et des régions voisines (Ptéridophytes et Spermatophytes), Jardin Bot. Nat. Belg., Meise, 5eme éd. , $130+1167$ pp.

Langlade, L.-R., Décamps, O., 1994. Plant colonization on rivers gravel bars: the effect of litter accumulation. C. R. Acad. Sc. Paris, Sci. de la vie 317, 899-905.

Langlade, L.-R., Décamps, O., 1995. Accumulation de limon et colonisation végétale d'un banc de galets. C. R. Acad. Sc. Paris, Sci. de la vie 317, 10731082.

Leclercq, L., 1984. Composition chimique des eaux des rivières oligotrophes de Haute Ardenne (Belgique) et ses variations saisonnières. Physio-Géo 9, $139-152$.

Legendre, P., Legendre, L., 1998. Numerical Ecology. Elsevier Science B.V., Amsterdam, 853 pp.

Lemin, G., Koch, G., Hutgen, C., Pissart, A., 1987. Les transports en suspension de la Meuse, l'Ourthe et la Hoëgne. Bull. Soc. Géogr. Liège 22-23, 39-61.

Petit, F., 1995. Régime hydrologique et dynamique fluviale des rivières ardennaises. In: Demoulin, A. (Ed.), L'Ardenne, Essai de Géographie, physique. Livre en hommage au, Prof., A., Pissart, Université de Liège, Liège, pp. 194-217.

Petit, F., Pauquet, A., 1997. Bankfull discharge recurrence interval in gravel bed rivers. Earth Surf. Process. Landforms 22, 685-693.

Petit, F., Schumacker, R., 1985. L'utilisation des plantes aquatiques comme indicateur du type d'activité géomorphologique d'une rivière ardennaise (Belgique). Colloques phytosociologiques 13, 691-710.

Petts, G.E., 1984. Impounded Rivers. Perspectives for Ecological Management. John Wiley \& Sons, Chichester, 326 pp. 
Riis, T., Sand-Jensen, K., Larsen, S.E., 2001. Plant distribution and abundance in relation to physical conditions and location within Danish stream systems. Hydrobiologia 448, 217-228.

Sand-Jensen, K., Pedersen, M.F., Laurentius, S., 1992. Photosynthetic use of inorganic carbon among primary and secondary mater plants in streams. Freshwater Biol. 27, 283-293.
Schumacker, R., 1976. Bref aperçu des groupements végétaux des fonds de vallée inondables de Haute Ardenne orientale. Colloques phytosociologiques $5,249-258$.

Williams, G.P., Wolman, M.G., 1984. Downstream effects of dams on alluvial rivers. US Geol. Surv. Prof. Paper, Washington, DC, 1286, 83 pp. 